\title{
La razón evaluadora entre temporalidades discontinuas y repartición de lo sensible. Del culto evaluacionista a una educación indisciplinada*
}

Fecha de entrega: 19 de septiembre de 2018 Fecha de evaluación: 22 de febrero de 2019 Fecha de aprobación: 10 de mayo de 2019

\author{
Facundo Giuliano ${ }^{* *}$
}

\section{Resumen}

Este ensayo se plantea como un montaje intertextual cuya metodología filosófica-estética apuesta a problematizar la configuración de temporalidades, regímenes escópicos y políticas de lo audible en las visiones hegemónicas del presente que configuran los dispositivos pedagógicos siempre atravesados por la razón evaluadora. Esto en busca de gestualidades ético-políticas cuya radicalidad dé lugar a temporalidades más igualitarias, que las supuestas por el tiempo productivo y cronológico de la escuela moderna/colonial. En este sentido, dicho planteamiento

* La investigación de este artículo surge en el marco de la investigación doctoral del autor, financiada por el Consejo Nacional de Investigaciones Cientificas y Técnicas de Argentina (Conicet), y que también se articula con su dirección del proyecto de investigación FiloCyT "Educación, filosofía y psicoanálisis: la potencia de un anudamiento indisciplinario frente al capitalismo contemporáneo" con sede en el Instituto de Investigaciones en Ciencias de la Educación de la Universidad de Buenos Aires.

Citar como: Giuliano, F. (2020). La razón evaluadora entre temporalidades discontinuas y repartición de lo sensible. Del culto evaluacionista a una educación indisciplinada. Cuadernos de Filosofía Latinoamericana, 41(122), 151-192. Dol: https://doi.org/10.15332/25005375/4643

* Licenciado en Ciencias de la Educación con estudios de posgrado en Filosofía, Psicoanálisis y Literatura (Universidad de Buenos Aires - Facultad de Filosofia y Letras).

Correo electrónico: giulianofacundo@gmail.com 
supone una dimensión crítica de la razón evaluadora que se discutirá a partir de la detección de algunos problemas y líneas de análisis como: (1) la configuración del evaluacionismo y sus valores como culto capitalista que coloniza la escuela; (2) la no-experiencia de la evaluación y las temporalidades del juicio, la acusación y la condena; (3) el tiempo evaluacionista que recicla la confesión en las nuevas prácticas de autoevaluación con sus respectivas operaciones de auto-culpabilización/ calumnia y "responsabilización”.

Palabras clave: filosofía de la educación, ética, razón evaluadora, evaluacionismo, evaluación, pedagogía, modernidad/colonialidad, juicio.

\section{Evaluating Reason, between Discontinuous Temporalities and the Partition of the Sensible. From the Evaluationist Cult to an Undisciplined Education}

\section{Abstract}

In search of ethical-political gestures whose radicalism gives rise to more egalitarian temporalities than those implied in the productive and chronological time of the modern/colonial school, this essay is laid out as an intertextual assembly whose philosophical-aesthetic methodology attempts to problematize the configuration of temporalities, scopic regimes, and policies of the audible in the hegemonic visions of the present that make up the pedagogical devices, which are always imbued by evaluative reason. In this sense, this approach implies a critical dimension of the evaluative reason that will be discussed based on the detection of some problems and lines of analysis such as: (1) the configuration of evaluationism and its values as a capitalist cult that colonizes the school; (2) the non-experience of the evaluation and the temporalities of trial, accusation, and sentence; (3) the evaluationist time that recycles confession in the new selfassessment practices with their corresponding self-blame/slander operations and "accountability". 
Keywords: philosophy of education, ethics, evaluative reason, evaluationism, evaluation, pedagogy, modernity/coloniality, judgment.

Dábase todo entero él al lleno de sus tareas, se mataba, devanaba los sesos estudiando, pasaba entre sus libros la mitad de su existencia y, ¿qué premio, qué recompensa, entretanto, conseguía, qué ganaba, qué valía, él quién era?

Eugenio Cambaceres, En la sangre

\section{Introducción: foco tentativo, intento de foco}

La escuela, heredada de la modernidad/colonialidad, se caracteriza por desarrollarse en un espacio recortado donde, mayormente, prima un uso cronológico-productivo del tiempo y cierta división de lo sensible. Por tanto, la pregunta emancipatoria al respecto no se ubica en relación a las posibilidades de mejoramiento de la gestión del uso del tiempo y el reparto de lo sensible, sino a las gestualidades ético-políticas cuya radicalidad discontinúe e irrumpa dicho tiempo para dar lugar a otras temporalidades más igualitarias. En este sentido, es necesario explorar algunas discusiones en torno a la noción de dispositivo para observar cómo opera pedagógicamente atravesado por la racionalidad evaluadora, al mismo tiempo que la razón evaluadora elabora sus propios dispositivos audio-visuales, a partir de los cuales cabe preguntarse sobre el lugar de lo estético en los procesos (educativos) de subjetivación. Aquí converge una serie de perspectivas que aloja vinculaciones entre las experiencias socio-culturales y los abordajes que piensan regímenes escópicos y políticas de lo audible, pero también una dimensión crítica de la razón evaluadora que se discutirá a partir de la detección de algunos problemas y líneas de análisis como: (1) la configuración del evaluacionismo y sus valores como culto capitalista que coloniza la escuela; (2) la no-experiencia de la evaluación y las temporalidades del juicio, la acusación y la condena; (3) el tiempo evaluacionista que recicla la confesión en las nuevas prácticas de autoevaluación con sus respectivas operaciones de auto-culpabilización/calumnia y responsabilización. Dicha apuesta se compone también de algunos excursos en los que se proponen discusiones específicas a propósito del legado moderno y la transmisión de la crueldad, para luego finalizar con una reflexión de lucha contra el juicio y a favor de una educación indisciplinada. 


\section{Fuera del foco moderno: notas para dejar de insistir con -o desengancharnos de- la modernidad/colonialidad y, por lo tanto, del juicio o la razón evaluadora}

¿Qué juicio de experto en arte podría referirse a la obra venidera? No tenemos por qué juzgar los demás existentes, sino sentir... si nos aportan fuerzas o bien nos remiten a las miserias de la guerra, a las pobrezas del sueño, a los rigores de la organización.

Gilles Deleuze, Crítica y clínica

Si bien es cierto que en una parte importante del pensamiento estético (y ético-político) contemporáneo confluyen, al menos, dos cuestiones complementarias: por un lado, el interés por volver sobre el pasado marginado de las narrativas dominantes para la configuración del presente, y, por otro, la necesidad de articular dispositivos teóricos adecuados para dar cuenta de estos problemas. No es menos cierto que, mayormente, ese pasado sobre el que se vuelve tiene como centro privilegiado a Europa y lo ocurrido allí a lo largo del siglo xx. Teniendo en cuenta este señalamiento, es importante remarcar la tendencia intelectual creciente por poner el terrible siglo xx europeo como punto de referencia ineludible para pensar la ética, la política y la estética, sin prestar atención a que todos esos genocidios tienen un origen colonial común, completamente emparentado con el surgimiento de la modernidad. Esta última no pensada como propia de los siglos XVII o XVIII —cuestión que no hace más que sepultar en el pasado los tiempos más oscuros de su surgimiento- y con la respectiva configuración geopolítica del mundo que implicó, sino a partir de finales del siglo xv y durante el XVI. En este sentido, se podría plantear la hipótesis — probablemente compartida con algunos pensadores y pensadoras latinoamericanos y decoloniales- que el horroroso siglo xx no ha sido más que la condensación y metonimia de aquello que comenzó cinco siglos antes, por allá en el 1492. En todo caso, la conquista de América, las colonizaciones sucesivas y la instalación de una matriz colonial de poder — de saber y de la subjetividad, como han enseñado Quijano y Mignolo, tal como ya señalamos en Giuliano (2019) - no puede pasarse por alto para pensar precisamente la ética, la política, la estética y, por ende, la educación. 
En la permanente confusión que se crea en el ámbito académico entre sus diferentes modos de hacer, de estudiar y de estar, aquella de los llamados estudios poscoloniales es un clásico hace ya un par de décadas. Con ese mismo nombre o etiqueta suelen meterse en la misma bolsa muchas posturas disímiles - y a veces antagónicas - entre sí, como es el caso entre los denominados estudios culturales, estudios subalternos, en relación con lo poscolonial y lo decolonial. Ciertamente comparten algunos autores y textos fuentes (como lo son Franz Fanon o Aimé Césaire, entre otros), pero la decolonialidad en particular ha buscado cuidadosa e insistentemente no quedar entrampada en las lógicas identitarias o particularistas típicas de lo poscolonial o de lo que viene siendo una moda importante hace un tiempo, las llamadas epistemologías del sur. Resumidamente, la decolonialidad no se define por ser un mero campo de "estudios", sino por un modo de hacer y estar en el mundo. Al mismo tiempo, su apuesta va por el lado de una epistemología fronteriza que surge de habitar la barra que une y separa la modernidad de la colonialidad, por lo cual ya no puede leerse solamente "modernidad" sin su otra cara siempre presente: la colonialidad ${ }^{1}$.

Este rodeo, excurso o desvío inicial, nos sitúa por un instante fuera de foco, pero una pequeña discusión nos alerta de su importancia. Pues la modernidad/colonialidad ha establecido desde su comienzo una suerte de ideología del juicio, que posteriormente ha tomado las formas del examen y la evaluación; y se (re)configuró como un tipo de racionalidad que en nuestra investigación hemos dado a conocer como razón evaluadora. Ella recoge la herencia de las ideas del juicio instaladas por la modernidad y que, como hemos señalado, se han condensado en los dispositivos confesionales de examen y evaluación. Esta razón evaluadora impele a comparar, calificar y normalizar a sujetos tan diferentes como singulares y opera en la acción con un principio de clasificación en el cual una representación educativa marca la distancia o cercanía de los sujetos respecto de un ideal de sujeto.

Ahora bien, la educación y con ella el arte de la enseñanza, desde dicho tipo de racionalidad, se ha tornado un mercadeo sin yapa, una labor mezquina con cierta doctrina del recelo que hace las veces de piedra de toque que separa o calibra lo reconocible de lo insignificante. Siguiendo este planteamiento, resulta curiosa la opción que proponen algunos autores de replegarse nuevamente a la modernidad (no sin colonialidad,

1 Para un abordaje detallado de esta cuestión se recomienda visitar Mignolo (2003) o la conversación al respecto en Giuliano (2017). 
como se ha señalado), buscando allí "lógicas emancipatorias" y "rescatar" los valores de la Ilustración. En esta clave, la propuesta de "recomposición de una modernidad" (Bourriaud, 2009, p. 27) en contraposición al posmodernismo descuida los nuevos modos de estandarización que dicen querer combatir y que se encuentran en el núcleo duro de lo moderno/colonial. Por esto, resulta cuando menos extraña la operación propuesta de arrancar dichos valores de los esquemas binarios y jerárquicos de la modernidad sin caer en cierta regresión fundamentalista favorable a la inmensa máquina del juicio - que supone la matriz colonial del poder- y a su configuración contemporánea, vista en la racionalidad evaluadora. Así planteado, el problema no trata de dinamitar la propia lógica cruel del juicio, sino de una mera cuestión de criterios "igualitarios" para establecer un juicio en un espacio de discusión.

El debate se complica aún más cuando se confunde lo posmoderno (siempre multicultural) con lo intercultural y se piensa que una lucha contra el juicio (sea este más o menos crítico) se da como una especie de "cortesía estética posmoderna" que se niega a él "por miedo a herir la susceptibilidad del Otro". Podría acordarse con Bourriaud (2009) que a menudo el motivo clásico (y por demás trillado) del "reconocimiento del otro" ciertamente equivale a "incrustar su imagen en un catálogo de diferencias" (p. 28), pero lo que no termina de ver es que el afán de respeto, traducido a veces en condescendencia y otras en cortesía, termina por alimentar la lógica violenta y racista de la colonialidad ${ }^{2}$. No obstante, dicho autor no repara en los aportes de la filosofía intercultural y directamente no ve un espacio cultural común (como la escuela ha sido desde siempre, más allá de sus lógicas internas de colonialidad), porque ha sido desocupado desde la quiebra del universalismo modernista; esto lo lleva a afirmar una mirada romántica del Otro (reificado) como representante de lo Verdadero y dueño de un lugar de enunciación separado por un tabique del resto. Claro que la lógica multicultural del capital ha implicado este manejo en muchos aspectos, bastaría con visitar el clásico ensayo de Žižek (1998) a este respecto, pero un gran favor le hace al legado moderno/colonial el seguir insistiendo en las fórmulas de un "receptor ideal que posea las propiedades de un decodificador universal" o seguir renegando de "aceptar la idea de que el juicio debe quedar en suspenso indefinidamente” (Bourriaud, 2009, p. 30);

2 Bourriaud (2009) dice que, en todo caso, el "respeto por el otro" genera un "colonialismo al revés, tan cortés y aparentemente condescendiente cuanto violento y negador fue el predecesor" (p. 28), pero esta idea del "colonialismo al revés" asi como la del "racismo invertido" en realidad el efecto que producen es el ocultamiento de las lógicas propias de la colonialidad que, al decir de Mignolo (2003), ya tiene que ver con un colonialismo sin colonias. 
Deleuze (1996) lo ilustra de manera antagónica en su idea de acabar de una vez con el juicio y Horacio González (2008) en su idea de sustracción (o de sustraerse) del juicio que se revuelve en la incógnita de un "imposible juzgamiento" (p. 127).

Por lo demás, sabemos que la utopía neoliberal actualmente aloja a lo multicultural como una estrategia privilegiada y ha hecho de los arraigos culturales o arraigos étnicos un sistema de pertenencias categóricas donde cada uno se ve así localizado, matriculado, petrificado en su lugar de enunciación o encasillado en la tradición de la cual provendría. Bourriaud (2009) está en lo cierto cuando señala la excesiva preocupación crítica por el lugar desde donde se habla como si este fuera siempre el mismo (uno solo) y se dispusiera de un solo tono de voz o un solo lenguaje para expresarnos. La lógica del juicio y la razón evaluadora operan en este registro, pidiendo a los sujetos que enuncien su identidad para facilitar su clasificación. En el afán de la lucha visibilizatoria (o bi-civilizatorio) contra la opresión y le negación, el capitalismo se adelantó unos pasos y la condena nos ha llevado a una "prisión domiciliaria simbólica" con libertad condicionada a una identidad (fetichizada) y un régimen de visitas a "parques temáticos esencialistas" (Bourriaud, 2009, p. 37) donde solo podemos hablar de lo que nuestra identidad nos habilitaría.

Kusch (2007) parece haberlo visto más temprano cuando dijo que el pensamiento no se ve ni se toca, pero pesa, está gravitado por el suelo que habitamos. No dijo que el suelo siempre fuera el mismo, ni tampoco el pensamiento, ni mucho menos quien piensa. Hay un peso, un suelo y una gravidez del pensar que no pueden perderse de vista. No es mera asignación territorial, sabemos bien de nuestro nomadismo e inquietud constitutiva, pero tampoco somos un diseño global (como muchas de las grandes teorías europeas del conocimiento) ni mera historia local (como el poscolonialismo pareciera reivindicar). Porque no hay vuelta atrás habitamos una barra, una frontera, la cual junta y separa "historias locales/diseños globales" (Mignolo, 2003). No se trata de separaciones identitarias, ni de reclamos de reconocimiento, ni de visibilizar lo negado, sino de otra opción: una que intenta des-engancharse de la lógica moderna/colonial, que no busca una "modernidad específica del siglo xxI" a partir de la "cooperación cultural" que, traducción mediante, aportarían a constituir una "altermodernidad”, como plantea Bourriaud (2009, p. 42); porque ya sabemos que implicaría más colonialidad u otra colonialidad o, para seguir el trazo, una altercolonialidad. ¿Acaso no se atisba una nueva forma de colonialidad o altercolonialidad cuando se plantea la construcción de un espacio de negociaciones que "superarían el multiculturalismo posmoderno, 
más atento al origen de los discursos y de las formas que a su dinamismo" (Bourriaud, 2009, p. 44)? Nuevamente un nuevo régimen de sustitución se propone: lo viejo por lo nuevo, lo salvaje por lo civilizado, lo (pos) moderno por lo altermoderno, el rizoma por el radicante, la pregunta por la procedencia por la del destino. Y no hacemos más que girar en el círculo vicioso de la modernidad/colonialidad.

El autor en cuestión propone retomar la pregunta moderna por excelencia: “ ¿A dónde ir?", lo cual juntaría no solo a quienes provienen de un mismo lugar (sea este una cultura o una "comunidad de intereses"), sino también a quienes se dirigen hacia un mismo lugar, aunque este permanezca impreciso e hipotético. Hasta los conquistadores hubiesen estado de acuerdo, pero leámoslo de primera mano en su definición de acontecimiento moderno:

\begin{abstract}
El acontecimiento moderno, en su esencia, se presenta como la constitución de un grupo que atraviesa, arrancándolos, las pertenencias y los orígenes: sea cual sea su género, su clase social, su cultura, su origen geográfico o histórico o su inclinación sexual, constituyen un grupo definido por su dirección y su velocidad, una tribu nómada sin el lastre de un anclaje anterior, de cualquier identidad fija. (Bourriaud, 2009, p. 47)
\end{abstract}

Tal vez sea redundante hacer de esta cita una rememoración de la Conquista de América, pero el asunto no anduvo muy lejos del arrancar las pertenencias y los orígenes, definir grupos por dirección y velocidad o forzar tal o cual grupo humano al nomadismo prescindiendo de las memorias históricas de cada pueblo. Esta es una buena prueba de que la retórica de la modernidad/colonialidad sigue siendo contemporánea y reconfigurándose a sí misma en cada nuevo tiempo, pues una modernidad del siglo xxi por más políglota y traductora que se pretenda no deja de jugar favorable a la colonialidad, aunque Bourriaud (2009) crea lo contrario al considerar que la misma nace de "negociaciones planetarias" (siempre asimétricas) y "descentralizadas" (p. 47) entre actores de culturas diferentes. De aquí lo propio del radicante, que estaría en un sujeto negociador que compite por ser más móvil que el capitalismo, inventando nuevas significaciones a la flexibilidad, a la larga duración, al dinamismo, a los arraigamientos sucesivos en detrimento del origen único, la experimentación y el circuito, en lugar de la permanencia y la construcción, la capacidad de adaptación o aclimatación a contextos diversos y a los productos (ideas, formas, etc.) que generan las “aculturaciones temporales” (Bourriaud, 2009, p. 58). Podría decirse sin más 
es casi un perfil completo (y renovado) del empresario o del sujeto neoliberal. Pero, ante estos avances, ¿qué lugar queda para la educación y la escuela ante la vorágine evaluacionista del capitalismo contemporáneo?

\section{El evaluacionismo como religión: notas sobre el culto capitalista en la escuela}

Alguna vez se dijo que la escuela, como una iglesia humilde, ha sido construida con piedras que estaban destinadas a forjar una gran catedral. Tal vez no haga falta mucho para pensar que la modernidad ha hecho de ella un espacio de culto a sus símbolos, íconos e ideales más fundamentales y que, una vez muerta, seguiría su sombra ilustrada habitando las cavernas de la formación. En tiempos donde toda una casta intelectual se regocija por clamar el retorno a los viejos valores de la Ilustración y plantear alguna nueva ilustración radical, conviene ver la sombra entre tanta luz o prestar atención a la sombra ilustrada que todavía no ha sido vencida. En este sentido, cabe pensar si el evaluacionismo contemporáneo no se trata acaso de la religión que el capitalismo en su fase actual ha impuesto para la cultura en general y para la escuela y la educación en particular.

Si hacemos eco al clásico texto de Walter Benjamin, "El capitalismo como religión”, podríamos decir que el evaluacionismo (como culto ${ }^{3}$ específico que el capitalismo ha impuesto a la escuela) tiene significado solo de manera inmediata con relación al utilitarismo y es de duración permanente (pensemos, desde ya, en la evaluación permanente o continua). Al igual que el capitalismo, el evaluacionismo tiene cierta relación con el engendramiento de la culpa y la deuda (recordemos que en alemán para ambas palabras existe una sola: $s c h u l d)^{4}$ : hace del estudiante un deudor de conocimientos o

3 Decimos "culto" porque este se trata siempre de una manifestación pública (exotérica) o, para este caso, de una manifestación en lo público. Pues tanto la escuela como la educación son patrimonio histórico de lo público y hoy se ven ciertamente colonizadas por dicho culto evaluacionista que impone "sacrificios" más o menos simbólicos en nombre del capital cognitivo (o humano), de la "calidad", de la competencia y el desarrollo. Como tal, el culto evaluacionista suele representar cierto "factor de estabilidad" para la comunidad educativa devota de la razón evaluadora, cuyo lazo se va consolidando por el planteamiento de una serie de ceremonias, rituales y objetos que el lector de este texto puede evocar al hacer memoria de sus propios procesos evaluativos.

4 Aqui es oportuna la notación de Deleuze (1996,) sobre la manifestación de Nietzsche respecto de la condición del juicio como "conciencia de tener una deuda para con la divinidad" (p. 176), lo que la vuelve infinita e impagable. De aqui que el sujeto solo recurre al juicio, "sólo es juzgable y sólo juzga en tanto en cuanto su existencia está sometida a una deuda infinita" (Deleuze, 1996, p. 177). 
aprendizajes, a la vez que sus dispositivos están preparados para autoresponsabilizarle por el resultado obtenido, aunque esto implique su propia abyección o descalificación al interior del sistema escolar. Los intereses acumulados, que como tales son una función de la culpa, juegan a favor de la deuda en tanto propiedad redentora del saber con el capitalismo: el mercado del saber hace las veces de balance redentor.

Pues, como sostiene Agamben (2005), la religión está relacionada con una operación de sustracción: sustrae cosas (aunque también lugares y personas) “del uso común y las transfiere a una esfera separada" (p. 98). Desde este punto de vista, no hay religión sin separación y toda separación aloja en sí un núcleo auténticamente religioso. Por esto, resulta tentador pensar lo religioso de la escuela como un dispositivo pedagógico que desde su configuración moderna rinde culto al evaluacionismo y a la razón evaluadora que lo sustenta. La lógica del sacrificio entra de lleno en la regulación de este dispositivo, ya que a través de una serie de rituales, más o menos burocráticos pero siempre minuciosos, se bautiza el pasaje de lo profano a lo sagrado a modo de un umbral por el cual el sujeto tiene que pasar para ser reconocido. A este culto no se opone la incredulidad o la indiferencia, sino la actitud libre del a veces distraído que franquea las normas de separación, repartición, uso o prohibición. Aquí reside la potencia emancipatoria de una distracción que posibilita un juego de usos singulares y permite profanar la escuela de sus elementos religiosos, como el culto evaluador. Lo cual permite atender a la observación de Agamben (2005):

Todo dispositivo de poder es siempre doble: él resulta, por un lado, de un comportamiento individual de subjetivación y, por el otro, de su captura en una esfera separada. El comportamiento individual en sí no tiene, a menudo, nada censurable y puede expresar más bien un intento liberatorio; es reprobable eventualmente - cuando no ha sido constreñido por las circunstancias o por la fuerza- solamente su haberse dejado capturar por el dispositivo. (p. 118)

Si las escuelas no son las criptas y mausoleos de la Ilustración, nos resta el ejercicio de andar por sus pasajes, sus intersticios, sus pasillos y túneles secretos en pos de profanar todo lo sagrado que en ella habita. A este respecto, El libro de los pasajes de Walter Benjamin resulta una invitación más que pertinente para profundizar algunas claves del presente análisis. 


\title{
Los valores del evaluacionismo en la escuela: un ejercicio de fagocitación a propósito de lo que el Marx de Benjamin invita a pensar
}

\begin{abstract}
La huella es la aparición de una cercanía, por lejos que pueda estar lo que la dejó atrás. El aura es la aparición de una lejanía, por cerca que pueda estar lo que la provoca. En la huella nos hacemos con la cosa; en el aura es ella la que se apodera de nosotros. (Benjamin, 2005, p. 450)
\end{abstract}

La escuela y su evaluacionismo se caracterizan por dejarnos huellas e instalarnos, no pocas veces, en un aura traumática que remite a sus elementos más propiamente sagrados e incuestionables. La modernidad instaló y consolidó la sinonimia entre educación y examen (hoy evaluación), que ha consolidado el dispositivo pedagógico a partir de una racionalidad primordialmente evaluadora. Si bien esto será motivo de un análisis posterior, interesa ahora introducirnos en la reflexión de lo que este tipo de racionalidad, que coloniza la escuela hasta nuestros días, es capaz de producir con su culto evaluador.

No faltan pedagogos que sostienen la idea de que a la escuela se va a trabajar $y$, como en todo proceso de producción y mercadeo, el proceso y el producto deben ser valorados en medio de un intercambio que produzca réditos para las partes involucradas en esta suerte de negocio. De este modo, el estudiante produce el capital humano que a su vez lo produce a como productor, su existencia se ata así a la producción de sí mismo como capital que muchas veces "determina el contenido de su vida de un modo que le resulta indiferente" (Benjamin, 2005, p. 664). Esta autoproducción o autoalienación educativa no puede pensarse sin su correlato evaluativo que hace de dicho proceso de trabajo un signo del valor de algo más. Así, la razón evaluadora y su culto hacen que docentes y estudiantes se relacionen unos con otros como si se tratase de un proceso de intercambio de mercancías cuya potestad radica en el valor de lo intercambiable: podría decirse una enseñanza por un "aprendizaje”, un conocimiento por una prueba de su introyección, un saber por una verificación de la memoria, una mezquindad a cambio de un reconocimiento cifrado. En palabras de Marx:

Para... relacionar mutuamente las cosas como mercancías, sus guardianes tienen que relacionarse unos con otros como personas cuya voluntad anida en esas 
cosas. [...] El valor... transforma todo producto de trabajo en un jeroglífico social. Más tarde, los hombres intentan descifrar el sentido del jeroglífico, intentan penetrar en el misterio de su propio producto social, pues la determinación de los objetos de uso como valores es un producto social suyo tanto como lo es el lenguaje. (Como se cita en Benjamin, 2005, pp. 668-669)

El carácter fetichista del reconocimiento evaluador prueba que la forma general del valor presenta los productos del trabajo pedagógico como mera expresión socioeducativa de la mercancía. De aquí la premisa económica liberal de que solo el trabajo crea valor y hace del vínculo educativo un vínculo mercantil donde lo que se intercambia son cantidades de trabajo. Así, la educación se dirime entre el valor de uso (como cualidad de una mercancía que tiene utilidad para otros) y el valor de cambio (capacidad para crear valor y plusvalía para el productor-capitalista) que le dan forma de inversión cual mera mercancía. Agamben (2005) insinúa un tercer término que sería el valor de exposición: "No es valor de uso porque lo que está expuesto es, en tanto tal, sustraído a la esfera del uso; no es valor de cambio porque no mide en modo alguno una fuerza de trabajo" (p. 117), quizá su fuerza radica en un mero dar a ver como cuestión inaprehensible. Como un ejercicio que ya no tiene que ver con el trabajo, sino con determinado uso no-cronológico del tiempo libre.

Pero la confrontación con la lógica del trabajo en la escuela no puede darse sin conspiraciones y cierta camaradería, lo cual supone un conflicto insalvable con los tribunales del orden mercantil. Pues difícilmente un mercader de la educación puede apoyar su liberación como ocio y tiempo libre, o el devenir cazador del estudiante que se ejercita en el bosque del texto, aguzando el oído para escuchar el crujido del animal tímido del pensamiento. El mercader de la educación, quizá como la figura del “divulgador” en filosofía ( la comercialización o tecnificación de la experiencia, de la desigualdad de las inteligencias, de la evaluación sensacionalista que homogeniza todo lo que aún tenga "visos de sabiduría, de tradición oral, de ser el lado épico de la verdad” (Benjamin, 2005, p. 803).

\section{La no-experiencia de la evaluación}

Si hay algo que caracteriza a la razón evaluadora y su culto probablemente sea ese procedimiento cotidiano, ritualizado, ficticio, de trazar caminos de antemano e imponer a los sujetos el paso por determinados lugares de ciertos discursos, es decir, el 
cumplimiento de objetivos pretrazados que reducen el accionar del sujeto a un andar manipulado y guiado cual laberinto para ratas de prueba. Agamben (2011) ha advertido acerca de la incompatibilidad entre la experiencia y la certeza desde el punto en que la experiencia una vez que se convierte en calculable pierde inmediatamente su autoridad. En este sentido, "[l]a certificación científica de la experiencia [...] permite deducir las impresiones sensibles con la exactitud de determinaciones cuantitativas" que buscan "prever impresiones futuras" desplazando la experiencia en favor de "los instrumentos y los números" (Agamben, 2011, p. 14). De este modo, ya no hay lugar para lo indecible, sino que todo queda expuesto primando la lógica del máthêma, una lógica que opera a partir de "algo que desde siempre es inmediatamente reconocido en cada acto de conocimiento" (Agamben, 2011, p. 21). Así, el sujeto es conocido por medio de sus predicados, que producen el enredo en un perpetuo círculo en el que la razón evaluadora se sirve siempre de su representación para juzgar algo de dicho sujeto.

Tal vez una de las cuestiones principales de la razón evaluadora y la disposición evaluacionista tenga que ver con la mutua imbricación entre la posibilidad de prever o conocer algo con certeza y la experiencia de un aprender cierto; saber únicamente a través y después de un padecer, a diferencia de lo que Agamben (2011) observa en la caracterización que Esquilo hace sobre el saber humano - contra la hýbris de Agamenón- como un páthei máthos cuyo aprendizaje excluye toda posibilidad de previsión o conocimiento de algo con certeza. Pues en el dispositivo evaluador se unen las ceremonias de lo previsible y cierta noción de aprendizaje asociada al sacrificio, esfuerzo o padecimiento por el cual el sujeto debe pasar para ser, en el mejor de los casos, a-probado, re-conocido, certificado.

En esta historia típica del progreso continuo y del tiempo crono-lineal, no hay lugar para la experiencia más que como forma de resistencia, o re-existencia, de infancia que traza un intervalo, una aventura, una discontinuidad como epojé. Pues si, como sostiene Agamben (2011), "la ausencia de camino (la aporía) es la única experiencia posible" (p. 34), la aventura deviene el camino hacia la experiencia que pasa por lo extraordinario de un viajar hacia la infancia y a través de la infancia ${ }^{5}$. Pero al culto

5 Aqui resulta interesante el pensamiento de Walter Kohan (2004) cuando afirma una noción de infancia ligada a la asunción de una "discontinuidad como condición ontológica de la existencia, una apertura experiencial a lo imprevisto, a lo que puede ser de otra forma, a lo que todavía no sabemos ni podemos [...] una 'figura del comienzo', en el sentido de una imagen que da lugar a la posibilidad de un porvenir abierto, inesperado, inesperable, según la lógica previa a la ruptura que ella introduce; 
evaluacionista y su racionalidad lo que le importa es en ¿qué se transformará la infancia?, ¿cuáles serán los puntos de llegada (pre)determinados según los objetivos, las necesidades socio-mercantiles o las metas de algún gobierno de turno (porque pareciera que, en su gran mayoría, de derecha a izquierda, todos coinciden en el culto evaluador y están motivados por sostener su tipo de racionalidad)?

Con lo cual, mientras neoliberales y progresistas de diverso cuño se sientan orgullosos a compartir la gran mesa de la evaluación — no sin discusiones a su interior, por supuesto, en la que cada uno quisiera convencer(se) de tener "la mejor evaluación"-, nuestra posición (que aloja adeptos filosóficos de distintos lugares y posturas) intenta entender esta razón evaluadora como un inconveniente o un defecto luminoso que, en su excesivo iluminismo, demanda una especial atención a su lado más oscuro. De este modo, se abre una fractura educativa que deviene el lugar de una cita entre los tiempos y las generaciones: la falla o punto de ruptura es una exigencia de puntualidad "en una cita a la que solo es posible faltar" [énfasis, fuera del original] (Agamben, 2014, p. 23), porque una (trans)formación del presente implica un modo inédito de relacionarse con la lectura de los tiempos y las citas como encuentros al interior de una experiencia. Así, la puntualidad tiene que ver con el momento preciso y con la puntuación necesaria en medio de un texto en el que nos hacemos y nos (hace) falta. Faltamos a la cita porque no estamos en ella como único modo de hacernos presentes y habitar el gesto.

\section{Tiempos de la razón evaluadora: entre juicios, acusaciones y condenas}

Vivía en tiempos en que el éxito primaba sobre todo, en que todo lo legalizaba el resultado.

Eugenio Cambaceres, En la sangre

En su Idea del juicio universal, Agamben (2015) narra una escena en una corte de justicia: allí se reúnen las almas de los hombres de todas partes, "pero la jaula de los imputados ya está ocupada” (p. 107). Entonces son conducidas para que tomen asiento

un porvenir insospechado e insólito" (p. 279). Se trata de la infancia como devenir sin pacto, sin falta, sin captura; como desequilibrio, búsqueda, nomadismo, encuentro, multiplicidad en proceso, diferencia no numérica, sino en sí misma, libre de presupuestos, expresión de vida, vida en movimiento, en experiencia. 
en diferentes lugares que van desde el palco de los jurados a la platea del público. Cuando se anuncia el ingreso de la corte, el imputado, que en secreto ya se había puesto los hábitos del juzgador, sube rápido al asiento del juez. Tan pronto se abre la audiencia, arroja el ropaje y se desliza hacia abajo, primero al banco de la fiscalía y luego al de la defensa. En los momentos de pausa, sin consuelo, vuelve a sentarse en la jaula del imputado.

Para el autor, esta escena remite a la ocupación de Dios en un juicio (interminable) a sí mismo donde él juega uno por uno todos los papeles mientras los hombres, consternados, poco a poco abandonan la avejentada sala en silencio. La referencia a Dios en el metaanálisis de esta escena nos conduce nuevamente a Benjamin cuando, en "El capitalismo como religión", subraya que, si bien su trascendencia ha caído, Dios no está muerto sino que ha sido incluido en el destino humano - aunque oculto y solo en el momento culminante de su inculpación podrá ser invocado- (aquí podría agregarse un cuarto rasgo del evaluacionismo como religión que coloniza la escuela: el culto es celebrado ante una deidad o autoridad cuyas representaciones y, más aún, los pensamientos que se le dedican, vulneran el secreto de su maduración). Pero la referencia también nos conduce a Nietzsche (2013) cuando sugiere que "no nos desembarazamos de Dios porque continuamos creyendo en la gramática" (p. 68). A este respecto es interesante la observación de Mèlich (2014): "Dios sigue vivo en la gramática, porque Dios no es exterior a nosotros mismos, sino algo que hemos incorporado y corporizado, algo que ha conquistado nuestro cuerpo, nuestra mente y nuestro modo de habitar el mundo" (pp.45-46). Esto último se hace compatible con la idea de Agamben (2015) sobre "un juicio en el lenguaje que, como tal, nunca puede ser de veras resolutivo y es, en efecto, incesantemente pospuesto (de aquí la idea de que el juicio universal sucederá sólo al final de los tiempos)" (p. 107); antes bien, "un juicio es sobre el lenguaje mismo que, en el lenguaje, elimina del lenguaje al lenguaje" (p. 108). Siguiendo esta idea, sugiere dirigir el poder del lenguaje hacia el lenguaje mismo y que el ojo vea su punto ciego, y la prisión se encarcele, como única manera en que los prisioneros podrán salir.

Artaud compartió la idea de oponer al infinito la operación de acabar de una vez con el juicio de Dios. En este punto adquieren notoriedad las notas de Deleuze (1996) cuya observación muestra cómo "la lógica del juicio se confunde con la psicología del sacerdote" que desea juzgar o tiene que hacerlo: 
[...] lo que hace que el juicio sea posible es el acto de diferir, de llevar hasta el infinito: éste debe su condición a una relación supuesta entre la existencia y el infinito en el orden del tiempo. A quien se atiene a esta relación le es dado el poder de juzgar y de ser juzgado. (p. 177)

De este modo el juzgador puede ser juzgado y viceversa, alimentando la despótica máquina del juicio que se retroalimenta a sí misma y en la que los placeres de juzgar y ser juzgado equivalen en su (promesa de) goce. Así se juzga desde la propia parcela y se es juzgado a partir de una forma que confirma o destituye la pretensión del juicio, lo cual multiplica al infinito el juicio y hace del autocastigo un escollo por el cual es inevitable pasar:

Ya no hay más que juicio, y todo juicio se ejerce sobre un juicio. [...] Y es que el juicio implica una verdadera organización de los cuerpos, a través de la cual actúa: los órganos son jueces y juzgados, y el juicio de Dios es precisamente el poder de organizar hasta el infinito. De ahí la relación del juicio con los órganos de los sentidos. [...] Artaud presenta ese "cuerpo sin órganos" que Dios nos ha robado para introducir el cuerpo organizado sin el cual su juicio no podría ejercerse. El cuerpo sin órganos es un cuerpo afectivo, intensivo, anarquista, que tan sólo comporta polos, zonas, umbrales y gradientes. Una poderosa vitalidad no orgánica lo atraviesa. (Deleuze, 1996, pp. 180-182)

¿Cuántas veces al día cualquier aula se viste de corte, o jaula de imputados, haciendo de su pequeña comunidad una audiencia entre jueces y juzgados? El evaluacionismo y su racionalidad han colonizado la escuela en el nombre de cierto Dios, han invitado a que el juicio se haga infinito y a que sus actores y actrices vistan y desvistan los hábitos del juez, habitando a veces los fiscalizados tiempos de la defensa e, incluso, de la resistencia. Pero el dispositivo suele ser tan eficaz que ni la campana que anuncia el recreo libera a los estudiantes y los docentes de un lastre que ya se ha hecho parte del cuerpo. En algunos casos, el re-creo no es más que el espacio-tiempo de confirmación del credo juzgador: juzga que algo quedará. Y así ser juzgado para ser reconocido, pero también autoimputarse para poder imputar a otros potencia las posibilidades de ser el próximo juez. Y así autoevaluarse para evaluar a otros: la desgracia educativa de nuestro tiempo. Como si nos gustara ir de corte en corte, buscando juicios y no justicia, aunque a ratos nos toque habitar el lugar del imputado. No hay guerra contra el juicio, sino una lucha que está en marcha y que ni el sueño descuida. 
Cualquiera podría pensar que durante el tiempo del sueño se descansa del juicio, pero parece que allí se "encierra la vida en esas formas en nombre de las cuales se la juzga” (Deleuze, 1996, p. 181). Tununa Mercado (2006) lo pone de manifiesto en un pasaje titulado "Juicio Final" que corresponde al capítulo "Sueños" de un libro suyo de 1988. Allí narra lo que podría ser el paso, onírico o diurno, por un juicio o examen final:

Los nervios vibran como en un estertor. El desaliento cunde, amilana las tropas de la imaginación, los sueños se cubren de muertos que se sientan a dialogar con los vivos. [...] Allí no hay alimento, en el sentido más general del término [...], pero las bocas reniegan de toda exigencia. Estamos allí, vivos y muertos, en una suerte de confín en el que cualquier alegato defensivo o cualquier enmienda serían innecesarios. [...] Nuestros silenciosos compañeros, aun cuando no discuten nada, señalan con un gesto casi inadvertido una zona que ellos conocen bien, más allá del cerco de piedra que rodea el espacio en que estamos. [...] hemos aceptado sin temor la fragmentación que se descarga sobre nuestros cuerpos en ramalazos: errores, memoria, desatinos [...]. Es como si todos hubiéramos ido abortando la posibilidad del encauzamiento, del orden salvador, de la personalización. Pero los recorridos individuales, no obstante, no se dejan domeñar y conservan su argamasa, la materia de su estructura. [...] En lo más escondido de la fisura, se dibuja una forma; el pozo se deja poblar. [...] cada uno ata y desata los nudos de su propio ovillo agrupando los núcleos en una inmensa bola que terminará por incluirnos para finalmente deslizarse más allá del cerco señalado por los testigos. (Mercado, 2006, pp. 58-62)

La narración es impresionante por muchos sentidos, no solo porque desnuda el hecho de que en tal escenario no hay alimento y por lo tanto se niega al alumnus (sustantivo del verbo alere, cuyo significado sería alimentar o alimentarse, así como también sostener o fortalecer), sino porque se acompaña de un juego de seducciones del poder juzgador que busca capturar las singularidades y resistencias a sus formas. Así aparece la sensación de lo innecesario respecto de los alegatos defensivos y las enmiendas, al mismo tiempo que aparece una re-negación de la exigencia o el gesto inadvertido que señala un saber que derrumba los muros establecidos. Del mismo modo, la aceptación de la fragmentación corporal y, en contraste con esto, la travesía singular que no se deja domeñar y agrupa sus núcleos en la inmensa bola inclusiva que, por colectiva, podrá deslizarse más allá del cerco señalado (aunque también este deslizamiento pueda 
interpretarse como la trascendencia paranoica de la atmósfera juzgadora). Y es que lo que está en juego masivamente en esta cuestión es un juicio sin justicia, y por esto se entiende mejor aún el pedido de María Elena Walsh (2015):

Señora de ojos vendados

que estás en los Tribunales

sin ver a los abogados,

baja de tus pedestales.

Quítate la venda y mira

cuánta mentira. (p. 303)

\section{Autoevaluación, autoculpabilización, de la autocalumnia a la confesión: tiempos evaluacionistas de responsabilización}

La vivencia kafkiana de lo educativo en una sinonimia acrítica con lo evaluativo se acrecienta con una frecuencia cada vez mayor, a partir de lo cual el proceso evaluativo y el comparecer esporádicamente ante un tribunal — que no hace más que recibir la acusación que hacemos de nosotros mismos- se vuelven constantes ${ }^{6}$. Bajo esta lógica, el proceso nos lleva a un rendir de cuentas que (nos) evidencia un determinado proceso a partir del cual no pocas veces se nos pide juzgarnos, examinarnos o evaluarnos. La razón evaluadora y su culto evaluacionista disponen de la escena siempre de manera seductora, para dar con el consentimiento del otro, para hacerlo parte del propio proceso que lo marcará con una cifra o una letra que deberá cargar dentro y fuera del sistema. El dispositivo es efectivo, es eficaz, al tribunal ya no le hace falta acusar, sino tomar registro del acuse que el sujeto hace de sí ${ }^{7}$. Cualquiera está en condiciones de entablar un proceso calumnioso contra sí mismo: en efecto, como señala Agamben (2014), aunque haya inocencia y no haya culpa que verificar a priori, la autocalumnia

6 Una de las narraciones más crudas en este sentido, puede encontrarse en la novela de Cambaceres (2006), publicada originalmente en 1887, donde se narra el encuentro de un estudiante con la escena examinadora: "aislada y solitaria en medio de un ancho espacio, como un escollo en el mar, la silla del examinado, el banco de los acusados, el banquillo, se decia, [...] destinado a una muerte más cruel y más infamante mil veces que la otra" (p. 82).

7 Skliar (2011) ejemplifica claramente el cinismo de la razón evaluadora cuando lee espantado una definición de autoevaluación como el "acto en el cual el rol del evaluador y evaluado coinciden" (p. 153). 
del acusado basta para hacerse merecedor de una marca (para el sistema educativo podríamos pensar en una nota, cifra, letra, palabra-significante, entre otras) ${ }^{8}$.

Siguiendo la etimología propuesta por Agamben (2014), accusare deriva etimológicamente de causa, significa "poner en causa" (p. 34) y el ser puesto en causa, ser acusado, implica una pérdida de la inocencia y un devenir "cosa”, es decir, "objeto-causa de litigio" (p. 35)

[...] allí donde la culpa consiste en dar inicio al proceso, la sentencia sólo puede ser el proceso mismo. [...] el derecho responde transformando en delito la propia puesta en causa y haciendo de la autocalumnia su propio fundamento. No sólo, entonces, el derecho pronuncia la condena en el momento mismo en que reconoce la falta de fundamento de la acusación, sino que además transforma el subterfugio del autocalumniador en su eterna justificación. En la medida en que los hombres no dejan de calumniarse a sí mismos y a los otros, el derecho (es decir, el proceso) es necesario para decidir cuáles acusaciones están fundadas y cuáles no. De este modo, el derecho puede justificarse a sí mismo, presentándose como un baluarte contra el delirio autoacusatorio de los hombres ( $y$, en alguna medida, este realmente ha actuado como tal, por ejemplo, respecto a la religión). (Agamben, 2014, pp. 36-37)

Si la culpa da inicio a un proceso que implica cierta cosificación y objetualización conflictiva, el lenguaje jurídico muestra de este modo en la educación que la sentencia aprobatoria/desaprobatoria reifica el proceso mismo en el sujeto encausado. También en los marcos pedagógicos se imponen condenas, aunque haya falta de fundamentos en las acusaciones o autoacusaciones, pues de este modo se justifica el marco procesual en el afán de decidir qué acusaciones estarían fundadas de acuerdo a lo que el sistema espera.

8 "En el proceso romano, [...] la calumnia representaba una amenaza tan grave para la administración de la justicia, que se castigaba al falso acusador marcándole sobre la frente la letra K (inicial de $k a$ lumniator)" (Agamben, 2014, p. 31). Este podria ser uno de los origenes de cargar a cuestas con una marca en la vida pública de un sujeto con sus respectivas consecuencias, ya se trate de un promedio, una letra o una palabra-significante que lo atraviese.

9 Este litigio de índole moral no está relacionado con otros tipos de litigio como podría ser el litigio político del que habla Rancière (2012a) y que "se diferencia de todo conflicto de intereses entre partes dado que es un conflicto sobre la cuenta misma de las partes. No es una discusión entre interlocutores sino una interlocución que pone en juego la situación misma de interlocución" (p. 127). 
Es cierto que la autocalumnia no es necesariamente una confesión, ya que esta última implica una condena de sí, mientras que la primera contiene un elemento de falsedad que constituye, en el mismo acto de su enunciación (performativa), al acusador (condenable por su acusación solo si se reconoce su inocencia como acusado) y al acusado (en su imposibilidad de confesión). Aunque los límites sean muy delgados, a diferencia de la autocalumnia como mero procedimiento performativo, la confesión es un dispositivo que tiene una historicidad que la vincula a diferentes procedimientos que se han realizado a fines de su captura, sin mencionar las formas que ella ha tomado en sus reconfiguraciones contemporáneas propias de las técnicas disciplinarias (como el examen) o de las más allegadas al control (como la evaluación). En este sentido, y esto será abordado más adelante, siempre ha estado en relación con los dispositivos pedagógicos que llegan incluso a trascender las paredes del aula y la escuela.

Las relaciones entre confesión y verdad han adquirido notoriedad a lo largo de la historia, desde los regímenes soberanos e inquisitoriales donde la tortura era el procedimiento para arrancar una confesión hasta los regímenes republicanos y disciplinarios donde la confesión se admite con reservas y "para defender al acusado" (Agamben, 2014, p. 39). Habría que pensar aquí qué nuevas formas ha tomado la tortura como instrumento probatorio por excelencia y como forma de investigación de la verdad, ya que los efectos de la difusión de su práctica han hecho que la confesión se interiorice e introyecte pasando de ser algo que arrancar por la fuerza a transformarse en "algo que el sujeto, desde su conciencia, está obligado a declarar espontáneamente”, tal como lo indica Agamben (2014). Incluso se registran casos de personas que "confiesan sin ser acusadas o después de haber sido absueltas en un proceso", así "la confesión como 'voz de la conciencia' [...] tiene valor probatorio e implica la condena de aquel que confiesa" (p. 40).

Una de las figuras más nefastas que existen es la del médico que garantiza que el torturado no muera durante el suplicio, pues así busca evitarse el "daño colateral" en la búsqueda de la verdad. Pero si el verdadero fin del dispositivo emplea aún estas técnicas, de modos cada vez más cuidadosos o sutiles, para investigar o acceder a una verdad ¿qué formas toman los efectos colaterales al interior de estos dispositivos de subjetivación? Más aún, con los dispositivos de confesión (y de tortura) cada vez más sofisticados y acompañados de esa intención pedagógica colonizada por la razón evaluadora y el culto evaluacionista, ¿acaso el docente deviene en el médico que garantiza 
el proceso sin muerte - aunque no sin trauma-? Estas y otras preguntas se dirimen a diario en las instituciones educativas...

\section{Excurso I: transmisión de la crueldad}

En todo querer-conocer hay ya una gota de crueldad.

Friedrich Nietzsche, Más allá del bien y del mal

Da la sensación que la educación y, con ella, la escuela colonizadas por la razón evaluadora y su culto evaluacionista forman parte de los bienes culturales que tienen un origen que no podemos considerar sin horror. No hace falta mucha imaginación para darse cuenta que la modernidad/colonialidad probablemente ha sido la que desvirtuó horrorosamente la escuela en favor del juicio y la convirtió en un enorme dispositivo productor de examinación constante y, hoy, de evaluación permanente (cada vez más alejada de la etimología que la emparenta con el tiempo libre: scholè). Así, parafraseando a Benjamin en sus Discursos interrumpidos, debe su existencia no tanto a sus creadores como a la servidumbre anónima de sus contemporáneos. Siguiendo esta idea y nuestro planteamiento, podríamos decir que este bien cultural no se da sin cierta crueldad y, al igual que este, no está libre crueldad, tampoco lo está el proceso de transmisión en el que pasa de uno a otro. Como podríamos decir con Buck-Morss (1995), el proceso de transmisión cultural tiene un efecto reaccionario por su manera evaluadora/cosificadora que aparece como un "cortejo triunfal” en el que los dominadores "pasan sobre los que hoy yacen bajo tierra” (p. 316).

Como dice Mèlich (2014), la crueldad es "el resultado de una lógica que dota de significado a una ordenación del mundo" y esta se caracteriza por clasificar sus elementos según "lo que son" y tratarlos o considerarlos en función del "lugar que ocupan en la clasificación" (p. 40). De este modo, con cualquier intento de comprensión o conocimiento aparece la crueldad en forma de una lógica inevitablemente moral(izante) que se dirige a un sujeto por su pertenencia a una categoría/ontología definida por la clasificación. Por ende, se ejerce contra alguien que no ha hecho más que existir de un modo singular, se ejerce contra alguien por lo que supuestamente es para esta lógica y, por tanto, no genera culpa, remordimiento o mala conciencia a quien ejerce la acción, sino todo lo contrario: habita la seguridad o tranquilidad 
de haber cumplido con su deber, con su mandato (moral). Así intenta dar cuenta de la "totalidad del mundo y de la vida, porque se presenta como una lógica del sentido último en la que todo está resuelto" y encaja (pues nada queda descolocado ni deslocalizado, todo está en su sitio) y lo que no encaja tendrá que ser "normalizado, curado, expulsado o exterminado" (Mèlich, 2014, p. 133). Como no soporta que nada ni nadie pueda ponerla en cuestión, porque no tolera disonancias, disidencias, ni paradojas, en cualquier caso, o en todo caso, se trata siempre de ejercer una misma operación pedagógica y poner en marcha un mismo procedimiento educativo-evaluativo:

[...] a crueldad tendrá que formarse, tendrá que ser educada, porque es necesario aprender a ver al otro no como un singular, como alguien que tiene un nombre propio, sino como miembro de una especie, de una raza, de un género o de un grupo. Hay que formar la crueldad para no ver al otro como otro, sino como una categoría. [...] La crueldad es una manera de pensar, de normalizar, de vivir y de ser. No es un mero acto de violencia o de destrucción sino, sobre todo, una forma de vida, una forma de ordenar la vida, un modo-de-ser. [...] En cualquier caso, en todo caso, se trata siempre de ejercer la misma operación, de poner en marcha el mismo procedimiento: establecer un principio absoluto e indudable que permita de manera clara y distinta decidir a priori quién puede y debe ser respetado y reconocido y quién no. (Mèlich, 2014, pp. 110-133)

Es la idea misma de que no podría haber educación, ni formación, sin evaluación (o examen) la que aúna la crueldad no solo al bien cultural que supone la escuela, sino a su propia transmisión. Pues así la educación deviene mera formación en la moral $y$, por tanto, en la crueldad. Desde el planteo anterior queda evidenciado que no hay moral sin crueldad, ni crueldad sin lógica, lo cual nos forma y nos deforma en toda una manera de pensar y estar en el mundo. En este sentido, no se puede desconocer la impronta que la colonialidad tiene en todo este proceso: desde sus inicios, la moderni$\mathrm{dad} /$ colonialidad ha impactado en la configuración geopolítica del poder, del conocimiento y de la subjetividad. Además de Fanon o Césaire, Mignolo, Dussel y Quijano han aportado análisis claves a este respecto; no hay regímenes de ordenación ni de clasificación sin la lógica de la colonialidad operando en medio de estos accionares. Pues, probablemente, la colonialidad sea el principio (cruel) absoluto e indudable que permite, de manera clara y distinta, decidir a priori quién puede (y debe) ser respetado 
y reconocido y quién no. Algunos siglos de historia moderna/colonial, precisamente un poco más de cinco, dan sobrados ejemplos de esto.

\section{Excurso II: -"Me mataste" - dijo una estudiante a su docente luego del examen. Notas sobre la ciencia de matar}

Un episodio de la conocida serie Black Mirror, cuyo título ha sido traducido en España como "La ciencia de matar", ilustra de modo interesante la mencionada formación en la crueldad. Narra la historia de una organización militar que se dedica al exterminio de seres humanos mutantes denominados roaches (cucarachas, en castellano) y cuyos soldados al consentir su participación en la organización han accedido a un implante neuronal que funciona como dispositivo de realidad aumentada que potencia $y$ deforma la percepción, lo cual no solo procesa los sentidos del sujeto, sino que es lo que permite percibir a determinados sujetos como figuras monstruosas a exterminar. Claro que el implante de dicho dispositivo ahorra y adelanta todo el proceso (de) formativo que supone la propia lógica de la crueldad, pero esto no quita validez a los elementos del ejemplo que también funcionan en la razón evaluadora en cuestión: consentimiento del proceso (donde se asumen riesgos hasta la propia abyección), la imposición de una nueva óptica y de determinados sentidos (que impactan no solo de manera perceptual sino también epistémica y ontológicamente), la mismísima lógica racista de la colonialidad (que clasifica y jerarquiza a los sujetos según categorías pre-establecidas).

Lo analizado nos remite también a ciertos componentes de la ciencia moderna/colonial: la cantidad mensurable, las leyes del movimiento y el cálculo de fuerzas. Como si se tratase de tres ejes que imponen un determinado marco de inteligibilidad a partir del cual una sociedad juzga y condena aquello que la supera o no encaja (a veces por su inmedible inquietud, otras veces por la movilización de fuerzas incalculables, incluso por la propia lentitud y la habitabilidad de otros tiempos). Así, la escuela moderna/ colonial con su culto evaluacionista y su movimiento cruel e ininterrumpido de examen, hace daño a los ojos y a la cabeza, enhebra y desenhebra sus descargas incesantes de estímulos en los que va perdiendo, junto con la capacidad ética de la mirada, la potencia de la consideración. Queda en sus sujetos el exceder o transgredir todo aquello con lo que formaban cuerpo e interrumpir los lazos de esta racionalidad que tanto 
los jueces como los sacerdotes, a veces con máscaras de profesores, prescriben para la escuela. Pues si esta escuela, como la fábrica, el periódico y el manicomio, puede tejer los lazos de esta racionalidad, que tantos burócratas referenciados ordenan subsumirse a ella, tal es la partida que se juega ante nuestra vista: "se trata de liberar a la mirada de la doble captación de la descarga y la interpretación, de devolverle su soberanía que es acto, que determina el gesto justo" (Rancière, 1991, p. 104), o justo el gesto como acto subversivo que libra la mirada - al menos en parte - de las interpretaciones dominadoras y las descargas tecnoinformativas que nos atontan.

Para Agamben (2001), gesto es el nombre de una encrucijada, de "un fragmento de vida sustraído al contexto de la biografía individual", una praxis, que es reverso de la mercancía y deja que se precipiten en la situación los "cristales de esta sustancia social común" (p. 68). Gesto, entonces, como patrimonio subversivo de lo común, como intersección de la vida y el arte, del acto y la potencia, de lo general y lo particular, del texto y la elaboración, un espacio-tiempo donde se suspende no solo la mera lógica cruel identitaria, sino también la colonialidad de la razón evaluadora y su culto evaluacionista: gestualidad sin gestión, sin gestor, sin valor de uso ni valor de cambio, apenas un guiño que nos alienta a seguir jugando pero no al mismo truco. Gesto que se hace signo del tiempo y sus discontinuidades, mueca rotunda de lo indescifrable y seña de que el enigma permanecerá misterio aún.

\section{Dispositivo (pedagógico-evaluador) y reparto de lo insensible}

Nadie se desarrolla por juicio, sino por una lucha que no implica ningún juicio.

Gilles Deleuze, Crítica y clínica

Entre las largas discusiones de las últimas décadas a propósito de la cuestión del dispositivo, Larrosa (1995) ha sido uno de los primeros en teorizar esta noción llevándola al campo filosófico de la educación. Si bien resulta tentador hacer cierta genealogía de este concepto, e incluso plantear cierta relación con lo que se ha nombrado como matriz colonial del poder, dejaremos dicha aventura para otra ocasión ${ }^{10}$, ya que interesa

10 De todos modos, puede advertirse que esta discusión remite a los aportes realizados por Michel Foucault en sus cursos y en su Historia de la sexualidad, posteriormente siguieron esta pista pensadores como Deleuze, Agamben, Esposito y, recientemente, la filósofa Luciana Cadahia. En clave sociológica de 
aquí centrarnos en lo analizado a propósito del llamado dispositivo pedagógico y ver cómo insistentemente su planteamiento no está escindido de la razón evaluadora y, por ende, de cierto reparto de lo sensible.

Larrosa (1995) ha mostrado la lógica general de los dispositivos pedagógicos que "construyen y median la relación del sujeto consigo mismo como si fuese una gramática susceptible de múltiples realizaciones” (p. 261), que involucra “tecnologías ópticas (de autorreflexión), formas discursivas (básicamente narrativas) de autoexpresión, mecanismos jurídicos de autoevaluación, y acciones prácticas de autocontrol y auto-transformación" (p. 263). De este modo, el dispositivo pedagógico produce y regula, al mismo tiempo, textualidades identitarias e imágenes de la gente y de sus relaciones entre sí, lo cual implica cierto aprendizaje: las cualidades personales de cada quien pueden conocerse y evaluarse según ciertos criterios a partir de los cuales pueden cambiarse aspectos del sujeto en cuestión o proponerse metas de su transformación.

A diferencia de lo que algunos autores contemporáneos plantean, consideramos que los dispositivos pedagógicos no pueden pensarse independientemente del análisis que involucra las prácticas disciplinarias de normalización y control social orientadas a la producción de sujetos mediante tecnologías de clasificación y división (tanto entre individuos como en su interior) que los objetivan (como por ejemplo el examen); esto en cierto afán de pensar las nuevas configuraciones sociales (de los dispositivos, las instituciones y el poder, entre otras) como sustituciones de sus modalidades anteriores sin entrever líneas de continuidad o re-adaptaciones. El desplazamiento que Larrosa (1995, p. 284) lee en el Foucault que se preocupa por cuestiones como la confesión y las tecnologías orientadas al trabajo del sujeto sobre sí mismo —en relación a intentar establecer tanto la verdad de sí mismo como la clave de su propia liberación-, no deja de estar inscrito en la misma pregunta que atraviesa la obra de Foucault ${ }^{11}$ y que,

la educación, el pionero ha sido Basil Bernstein hacia finales de los ochenta, mientras que en clave técnico didáctica la principal precursora del mismo ha sido Marta Souto hacia finales de la década del noventa. Diferentes relaciones entre estas concepciones, a propósito de la razón evaluadora y la matriz colonial de poder, han sido analizadas y discutidas recientemente en Giuliano (2019).

11 Como cuenta Foucault (1994) en una de sus últimas y más conocidas entrevistas, su problema siempre ha sido el mismo, aunque haya formulado de manera un poco diferente el marco de su reflexión, a saber, "cómo el sujeto humano entró en los juegos de verdad, sea los juegos de verdad que tienen la forma de una ciencia o que se refieren a un modelo científico, o los juegos de verdad como los que uno puede encontrar en las instituciones o prácticas de control" (pp. 105-106). 
para el análisis en cuestión, no deja de aportar un nuevo elemento a considerar para el problema del dispositivo en general y de los dispositivos pedagógicos en particular.

Entonces, la cuestión de la confesión y las tecnologías orientadas al propio trabajo del sujeto sobre sí mismo invita a pensar, al interior de la cultura occidental cristiana, la relación entre los dispositivos pedagógicos, el gobierno (de sí y de los otros) y la subjetivación; esto en el marco de un poder pastoral que busca conocer lo que pasa por la cabeza de los individuos (sin forzarlos) para dirigirlos, lo cual exige, además de actos de obediencia y sumisión, actos de verdad en los que el sujeto diga la verdad de sí mismo, de sus faltas, sus deseos, etc.

El poder sobre uno mismo, del que el confesor es el primer depositario, pasa por la obligación de vigilarse continuamente y de decirlo todo acerca de uno mismo. Pasa también por una relación con el juicio, con el juzgar-se, puesto que establece una relación entre la subjetividad y la ley. La confesión es, igual que el examen en Vigilar y castigar, un dispositivo que integra la producción del saber y la ceremonia del poder, el lugar donde la verdad y el poder confluyen. El sujeto confesante es atado a la ley en la misma operación en que es atado a su propia identidad. Reconoce la ley y se reconoce a sí mismo en relación a la ley. La confesión es un dispositivo que transforma a los individuos en sujetos en los dos sentidos del término: sujetos a la ley y sujetados a su propia identidad. Promueve formas de identidad que dependen de cómo el sujeto se observa, se dice y se juzga a sí mismo bajo la dirección y el control de su confesor. (Larrosa, 1995, pp. 322-323)

Como puede notarse, los dispositivos pedagógicos son atravesados por la razón evaluadora porque implican, quizá constitutivamente, procesos de juzgamiento, examen y evaluación (de sí y de los otros). Esto delimita toda una política de lo audible (que demarca lo que debe o puede ser escuchado y lo que no) y determinados escópicos, pues se presta atención a la posición de los sujetos parlantes que producen una verdad sobre sí mismos, en los dispositivos que "hacen visibles (y escuchables)" a las personas que capturan (aunque nunca del todo). Así entra en juego lo que se ve y se hace ver, lo que se oye y se hace oír, así como también lo que se oculta, al interior de los dispositivos pedagógicos y sus regímenes de vigilancia, es decir, de visibilidad y escuchabilidad. Estos regímenes, compuestos por un conjunto específico de máquinas 
óptico-auditivas, abren el objeto a la mirada y a la escucha, a la vez que abren el ojo que mira y el oído que oye. Por esto, el sujeto se posiciona en función de la visibilidad y de la escuchabilidad de los dispositivos pedagógicos que hacen ver, oír y orientan su mirada y su escucha, de manera histórica y contingente. Con lo cual, habitar un dispositivo pedagógico implica aprender sus reglas de uso a propósito de los mecanismos ópticoauditivos que orientan determinadas maneras (correctas) de ver, oír y ser visto y oído.

Siguiendo a Larrosa (1995), vemos que los dispositivos pedagógicos (con todas sus prácticas, mecanismos o máquinas) enlazan visibilidades y enunciados, ópticas y audiencias, pero también "formas de ver y de decir que remiten a dichos dispositivos de los que emergen y se realizan” (p. 305). Esta capacidad de subjetivación es inherente a los dispositivos pedagógicos que tienen lugar en cada espacio-tiempo donde se aprenden/constituyen o se modifican las relaciones que el sujeto establece consigo mismo, como sostiene Larrosa (1995):

\begin{abstract}
Lo que sea el ser humano en tanto que mantiene una relación reflexiva consigo mismo no es sino el resultado de los mecanismos en los que esa relación se produce y se media. Los mecanismos, en suma, en los que el ser humano se observa, se descifra, se interpreta, se juzga, se narra o se domina. Y, básicamente, aquellos en los que aprende (o transforma) determinadas maneras de observarse, juzgarse, narrarse o dominarse. (p. 291)
\end{abstract}

Lo que los dispositivos pedagógicos producen y buscan capturar es la relación y la mediación, que tiene el poder de fabricar lo que relaciona y lo que media, lo que sucede entre. A este respecto basta con visitar la historia de la colonialidad para ilustrar claramente lo que dice Larrosa (1995): “es en el momento en que se objetivan ciertos aspectos de lo humano que se hace posible la manipulación técnica institucionalizada de los individuos" y, a la inversa, "es en el momento en que se despliegan sobre lo social un conjunto de prácticas institucionalizadas de manipulación de los individuos que se hace posible su objetivación 'científica"' (pp. 283-284). No obstante, pero en estrecha relación, merece la pena detenernos en las cinco dimensiones fundamentales que constituyen los dispositivos pedagógicos para Larrosa (1995, pp. 292-293):

1. Dimensión óptica: aquella según la cual se determina y se constituye lo que es visible del sujeto para sí mismo. 
2. Dimensión discursiva: esta establece y constituye qué es lo que el sujeto puede y debe decir acerca de sí mismo. Esta podría ser considerada también una dimensión auditiva, ya que, como hemos visto, los sujetos también ocupan una posición como sujetos parlantes al interior del dispositivo.

3. Dimensión jurídica: es básicamente moral y da las formas en que el sujeto debe juzgarse a sí mismo según una rejilla de normas y valores.

4. Dimensión narrativa: esta incluye componentes discursivos y jurídicos relacionados, es constitutiva de la identidad y está constituida en forma temporal; es la que determina, por tanto, qué es lo que cuenta como un personaje cuya continuidad y discontinuidad en el tiempo es implícita a una trama.

5. Dimensión práctica: esta establece lo que el sujeto puede y debe hacer consigo mismo.

Para este análisis a propósito de los dispositivos pedagógicos, la razón evaluadora y su culto evaluacionista no es para nada menor la aclaración que realiza Larrosa (1995) sobre la (pre)dominancia de la dimensión jurídica en relación a las demás, aunque "en ocasiones, existan fracturas, contradicciones y tensiones entre ellas", el juicio no deja de ser una "dimensión privilegiada de los dispositivos pedagógicos" (p. 320) porque juzgar(se) sería lo que hace decir(se) y ver(se). De este modo puede notarse cómo un dispositivo pedagógico deviene fácilmente en un dispositivo jurídico que "constituye, en su funcionamiento mismo, un juez, una ley, un enunciado y un caso"; cuestión que pone a la razón evaluadora, juzgadora por excelencia, a cargo de todo el dispositivo ya que

En el ámbito moral en tanto que normativo y jurídico, ver-se, expresar-se y narrar-se se convierten en juzgar-se. Y juzgarse supone que se dispone de un código de leyes en función de las que se juzga (aunque el sujeto sea considerado como autolegislador o autónomo). Supone que uno puede convertirse en un caso para uno mismo, es decir, que uno se presenta para sí mismo delimitado en tanto que cae bajo la ley o se conforma a la norma. (Larrosa, 1995, pp. 316-317)

Entre mecanismos ópticos y procedimientos discursivos, pero con primacía del afán jurídico, los dispositivos pedagógicos regulan la vida social y la razón evaluadora que 
los constituye les impele a juzgar, normalizar y encauzar a los sujetos que los habitan. De esta manera, procedimientos reflexivos de auto-observación, auto-expresión o auto-narración quedan vinculados a estos dispositivos que hacen a los sujetos capaces de juzgarse, gobernarse, conducirse de determinada manera y hasta comportarse como sujetos dóciles y obedientes. Pero resulta clave remarcar el señalamiento de Larrosa sobre la transformación o re-adaptación de estos dispositivos regulativos basados en la ley que comienzan a basarse en la norma o, a nuestro entender, la ley se recicla como norma en el marco de un funcionamiento no solo negativo, sino también positivo del juicio. El tipo de funcionamiento dependerá de la circunstancia, y esta es la eficacia de la moral (no de la ética que rompería con ella): será negativo cuando el juicio se formule - con arreglo a la ley - sobre el modelo de lo permitido y lo prohibido (lo cual también indica un horizonte de transgresión) al interior de procedimientos que siempre involucran alguna forma de exclusión social; y será positivo cuando el juicio se dé - con arreglo a la norma - en forma reguladora al interior de procedimientos de inclusión normalizadora/disciplinaria. En este sentido, la norma tiene aspectos más estratégicos que la ley, los cuales están vinculados a la formulación estadística, a la búsqueda de regularidades, a la generación de hábitos, a la pretensión de objetividad y justificación racional, a la pretensión descriptiva que es fuertemente normativa desde el punto en que establece un criterio productivo (lo normal) que juzga/valoriza negativa o positivamente.

La norma habita un conjunto de prácticas de normalización que, al mismo tiempo que producen lo normal, complejizan divisiones tales como inclusión-exclusión, lícito-ilícito, y dan lugar a categorizaciones donde lo normal posee calidad aprobatoria mientras que se reprueba, se patologiza o anormaliza todo aquello que se desvíe o exceda el criterio de discernimiento establecido por "lo normal" (sostenido por un conjunto de saberes, que fijan criterios racionales como objetivos, y encarnado en reglas de funcionamiento, que regulan la conducta según prácticas sociales de disciplina, de un conjunto de instituciones).

Por último, Larrosa (1995) resume la estructura y el funcionamiento de los dispositivos pedagógicos como "un conjunto de operaciones de división orientadas a la construcción de un doble y un conjunto de operaciones de relación orientadas a la captura de ese yo duplicado", lo cual implica que "[a]prender a ver-se, a decir-se, o a juzgar-se es aprender a fabricar el propio doble" y a "sujetarse a él”, con lo que describir los dispositivos pedagógicos sería describir "qué doble producen y cómo”, así como también 
qué es lo que de ese doble se captura y cómo, es decir, qué tipo de relaciones tiene uno que establecer con su doble. Las dimensiones del dispositivo no son otra cosa que la materialidad y las formas de realización de esas operaciones de fabricación y captura del doble. (pp. 323-324)

Aunque todo se produzca en forma simultánea, ninguna dimensión, espacialización, ni temporalización es previa al juicio, pues como bien dice Larrosa (1995): "Habría un mirar-se que es ya propiamente una operación jurídica, una forma de decir-se que es ya axiológica y normativa, y un narrar-se que ya está constituído en la forma del pasar-se cuentas" (p. 326). El doble es fabricado por y para el juicio, de modo que se constituye ya en un caso en sí mismo al haberse determinado bajo un criterio que lo marca positiva o negativamente y según su historia convertirse en un pasar o pasarse cuentas. Estas cuentas están atadas a un conjunto de operaciones de exteriorización; esto es, la forma en que el doble se convierte en una cosa exterior (y abierta a los otros) de los propios sujetos involucrados.

En esta suerte de exteriorización de lo interior al sujeto, aprender a juzgar o, mejor dicho, aprender a introyectar la razón evaluadora — racionalidad siempre juzgadora si las hay-, supone estabilizar o apuntalar la fragilidad, absorber o reducir la indeterminación, prevenirse de errores, saber ubicarse en tiempo y espacio para focalizar y adecuar la mirada, promover un discurso no ambiguo o una narración consolidada entre los criterios de lo verdadero y lo falso, lo bueno y lo malo, lo normal y lo anormal, entre otros. Así uno se convence de que no se ve, no se dice, no se juzga, no se domina sin ser, al mismo tiempo, visto, dicho, juzgado y dominado. Y esto en el interior de los dispositivos pedagógicos que alojan aparatos de producción de verdad, mecanismos de sumisión a la ley/norma, formas de auto-afección en las que uno mismo aprende a participar exponiéndose en las miradas (y las escuchas), "los enunciados, las narraciones, los juicios y las afecciones de los otros" (Larrosa, 1995, p. 327). De este modo, uno no sería otra cosa que el modo como se relaciona con su doble y así termina por naturalizar las operaciones de división y reparto que los dispositivos promueven con la razón evaluadora.

El mismo Larrosa (1995) señala lo evidente como resultado de "una cierta dis-posición del espacio, de una particular ex-posición de las cosas y de una determinada constitución del lugar de la mirada” (p. 328), lo cual nos lleva a pensar directamente en Rancière (2009) y su noción de reparto de lo sensible como ese "sistema de evidencias 
sensibles que al mismo tiempo hace visible la existencia de un común y los recortes que allí definen los lugares y las partes respectivas" (p. 9). Lo cual fija entonces, al mismo tiempo, un común (como podría ser la educación o los dispositivos pedagógicos para nuestro análisis) repartido y partes exclusivas; es decir que, por ejemplo, habrá sujetos que tendrán parte en el hecho de enseñar o ser enseñados, de evaluar o ser evaluados, de gobernar o ser gobernados, según establece el funcionamiento del dispositivo que reparte partes y lugares fundado en una disposición de espacios, de tiempos y de actividades que determinan su ofrecimiento participativo-inclusivo (aunque normalizador) y donde a unos corresponderán ciertas partes en determinados momentos y formas, mientras que a otros no (aunque puedan variar las partes correspondidas, los tiempos y actividades sobre ellas como ha podido observarse a lo largo del presente análisis sobre los dispositivos). En este sentido, para Rancière (2009) la otra forma de reparto que precede a este tener parte sería aquel que determina quiénes tienen parte en él (este procedimiento suele operar por categorías, lo cual nos remitiría nuevamente a la crueldad referida más arriba).

De este modo, la razón evaluadora y su culto evaluacionista, que alojan los dispositivos pedagógicos, funcionan mediante dicho reparto de lo sensible ${ }^{12}$, que hace ver quién puede tener parte en función de lo que hace, del tiempo y el espacio en los cuales determinada actividad pedagógica o educativa se ejerce, $y$, también, define competencias e incompetencias de acuerdo a tener tal o cual ocupación (lo cual también juega dentro de las coordenadas del régimen de visibilidad propuesto, es decir, quiénes serán o no visibles de acuerdo a lo que hagan en dicho espacio común dotando de un lenguaje común). Pues, siguiendo la huella estética de Rancière (2009), se trataría de un "sistema de formas a priori que determinan lo que se da a sentir" como un "recorte de tiempos y de espacios, de lo visible y lo invisible, de la palabra y el ruido que define(n) a la vez el lugar y la problemática" de la educación como "forma de experiencia" (p. 10). Pues la educación, tanto como la política (tal vez aquí se entienda un poco mejor por qué toda educación es política), trata de lo que vemos y de lo que podemos decir al respecto, sobre quién tiene la competencia para ver y la cualidad para decir, sobre las propiedades de los espacios y los posibles

12 Rancière (2010) también ha llamado división policial de lo sensible a "la existencia 'armoniosa' entre una ocupación y un equipamiento, entre el hecho de estar en un tiempo y un espacio específico, de ejercer en ellos ocupaciones definidas y de estar dotado de las capacidades, de sentir, de decir, y de hacer adecuadas a esas actividades", para lo cual la emancipación significa, de hecho, "la ruptura de este acuerdo entre una 'ocupación' y una 'capacidad'" (p. 46). 
del tiempo. El cuestionamiento de estos términos, el desacuerdo o disenso sobre "la evidencia de lo que es percibido, pensable, factible, y la división de quienes son capaces de percibir, pensar y modificar las coordenadas del mundo común”, abre un "proceso de subjetivación política: la acción de capacidades no contadas que vienen a escindir la unidad de lo dado y la evidencia de lo visible para diseñar una nueva topografía de lo [im]posible" (Rancière, 2010, p. 52).

Como conjetura final de esta extensa sección, luego de haber visto anteriormente diferentes operaciones de la crueldad, surge la tentación de pensar que cada reparto o división de lo sensible funda también cierto reparto de lo insensible, en el sentido de la indiferencia o la inmunidad — incluso la impunidad — ante esos otros que no tienen parte porque la propia lógica moral de los dispositivos así lo ha determinado. Así surge toda una parafernalia del mediador, del divulgador, del hábil que hace uso de su viveza para "ver por los que no ven" o hacer saber de la ignorancia de los otros pero nunca de la propia, una figura privilegiada del capitalismo actual y la impostura contemporánea que busca desplazar insistentemente la función emancipatoria de cualquier maestro ignorante cuya base de sustentación está en la confianza:

\section{[...] ese poder común de la igualdad de las inteligencias liga individuos, les hace intercambiar sus aventuras intelectuales aun cuando los mantiene separados los unos de los otros, igualmente capaces de utilizar el poder de todos para trazar su propio camino. (Rancière, 2010, p. 23)}

Esta confianza afirma que nadie puede ver por los que no ven o hacer saber de la ignorancia de los otros, porque el problema no es saber lo que se hace (como tantos mediadores, divulgadores o "habilidosos de la interpretación" sugieren), ni buscar por detrás la razón de las cosas; el problema es pensar en lo que se hace, "acordarse de uno mismo" como diría Rancière (1991, p. 102). Y aquí otro gesto fundamental como alternativa a la impostura de los doctos y sabios, devotos de la razón evaluadora y los dispositivos pedagógicos. 


\section{Excurso III: crítica embrutecedora y clínica patologizante}

Todas las teleologías y todas las imaginerías de la toma de conciencia se fundan en la certidumbre de un reparto: algunos tienen misión de hablar para los otros que no saben lo que hacen.

JACQUES RANCIÈRE, Breves viajes al país del pueblo

Es de destacar que, así como pervive una lógica moderna/colonial en los dispositivos pedagógicos y, en particular, en la escuela, tampoco puede reducirse sin más los acontecimientos que al interior de esta última se dan. Algunos lo han dicho y hecho de sobra: ir a la escuela a hacer escuela, incluso ir a la escuela por intentar que la scholè acontezca. En este sentido, la escuela podría responder a una de esas formas que imponen un límite al poder del mercado. Este último ha hecho de la democracia una compulsión a la satisfacción individual y de la igualdad el mercadeo que reina entre el vendedor y el comprador de una mercancía. Tomar conciencia de esta y otras cuestiones ha sido la empresa de variadas corporaciones (sociológicas, pedagógicas, políticas, psicológicas) que han hecho de la crítica interminable del sistema no solo una demostración de las razones por las cuales queda privada de todo efecto, sino, tal vez justamente por ello, "la certidumbre de un reparto: algunos tienen la misión de hablar para otros que no saben lo que hacen" (Rancière, 1991, p. 101). Así la crítica o, como diría Rancière (1991), la desmitificación ha sido arte y parte del "embrutecimiento, de una investidura del sistema de lugares y de las maneras de ocuparlos" (p. 107).

En efecto, los procedimientos de la crítica social (reificados en los dispositivos pedagógicos y que hacen "buen uso de la razón" evaluadora) buscan "curar a los incapaces", es decir, a quienes "no saben ver" o "no comprenden el sentido de lo que ven", a quienes no saben decir, leer y escribir como la norma manda, incluso a quienes "no saben transformar el saber adquirido en energía militante” (Rancière, 2010, p. 50). De esta manera, al mismo tiempo que se perfila la crítica como embrutecedora se plantea una clínica patologizante llena de curanderos de incapacidades que, para curarlas, necesitan reproducirlas indefinidamente. Como si se tratase de una enfermedad crónica, la época azota a los sujetos con un sinfín de nuevas capacidades (y por antagonismo performativo, incapacidades), a veces disfrazadas de competencias o habilidades para 
la vida, que deben adquirirse según el imperativo de las políticas educativas que tan afines al lenguaje y a la lógica del mercado suelen encontrarse. Desde ahí se establece todo un protocolo de transmisión del saber, basado en la instalación de un abismo y antagonismo en relación a la ignorancia que ubica de entrada al estudiante siempre en una posición de falta, lo cual lo supone allí para suturar esa falta, curar su incapacidad y hacerle devenir capaz en tal o cual área de conocimiento, hacerle dar el paso de la incompetencia a la competencia. Olvidamos así que el saber no es un conjunto de conocimientos, sino una posición que se ejerce a través de la interminable práctica del "paso adelante" que separa al docente de quienes se supone que han de ejercitarse para alcanzarlo. Rancière (2010) ilustra este proceso con la "metáfora del abismo radical que separa la manera del maestro de la del ignorante: el abismo separa dos inteligencias, una que sabe en qué consiste la ignorancia y otra que no" (p. 16), pero que debe aprenderlo a partir de su enseñanza, es decir, la enseñanza de una radical separación y de la propia incapacidad del estudiante. Y así los dispositivos se aceitan una y otra vez, las clínicas patologizantes se llenan de pacientes dependientes de sus curanderos y el embrutecimiento, que a veces se disfraza de retóricas críticas, no es más que la verificación interminable del presupuesto desigualitario puesto en acto desde el comienzo:

Es la lógica del pedagogo embrutecedor, la lógica de la transmisión directa de lo idéntico: hay algo, un saber, una capacidad, una energía que está de un lado -en un cuerpo o un espíritu-y que debe pasar al otro. Lo que el alumno debe aprender es lo que el maestro le enseña. [...] Lo que debe sentir es la energía que él le comunica. A esta identidad de la causa y del efecto que se encuentra en el corazón de la lógica embrutecedora, la emancipación le opone su disociación. Ese es el sentido de la paradoja del maestro ignorante: el alumno aprende del maestro algo que el maestro mismo no sabe. Lo aprende como efecto de la maestría que lo obliga a buscar y verificar esta búsqueda. Pero no aprende el saber del maestro. (Rancière, 2010, p. 20)

Transmisión de lo idéntico, transmisión de la crueldad, transmisión sin gesto, aunque con mezquindad. No hay pretensión emancipatoria que ubique algo en un tercer lugar, sino una propiedad de un lado que pareciera tener que adquirirse de otro. Todo parece reducirse a una lógica sacrificial por un mero derecho de propiedad y así, desde pequeños, nos vamos (de)formando en la lógica cruel capitalista, a no ser que caer en 
lo público nos brinde un ineludible espacio y un horizonte emancipatorio más acá y más allá del juicio con la razón evaluadora que hace tanto tiempo coloniza la escuela.

\section{Entonces, ¡luchar contra el juicio! Por una educación indisciplinada...}

Si se fuese, llegó a ocurrírsele de pronto, si faltase al llamado de la mesa... ¿Por qué no? - púsose a decirse en el vehemente empuje de su tentación, hostigado por el aguijón del miedo; ¿qué mal le resultaría, a qué mayor daño se exponía, qué le podía suceder, en suma, con proceder así?... Perder el año... y bien, iqué le importaba, si sabía que de todas maneras lo tenía perdido dando examen!

Eugenio Cambaceres, En la sangre

Rancière (2012b) afirma que la experiencia estética "escapa a la distribución sensible de los lugares y las competencias que estructuran lo social" en tanto "neutraliza la relación circular del conocimiento como saber" y como "distribución de espacios" (p. 285), y posibilita el desajuste del dispositivo. Así entra en juego un pensamiento que practica la ignorancia de las fronteras disciplinarias para conferir a los discursos el estatus de "armas de una querella", esto es, un pensamiento combativo que será señalado por Rancière (2012b) como “in-disciplinario" (p. 289) y que pone en escena el fragor de una batalla. Contamos, entonces, con dos nuevos elementos para una lucha contra el juicio, la razón evaluadora y su culto tecnocrático basado en objetivos prefijados o competencias a adquirir, así como también contra una concepción meramente disciplinaria del saber: aiesthesis e indisciplina o, mejor dicho, experiencia estética y pensamiento indisciplinado. En otras palabras, es lo que Horacio González (2008) postula con su idea de experiencia literaria como esa convivencia "con la estúpida y perturbada sensación de que nos detenemos - y esa detención es elástica y eterna- en la inminencia absoluta de poder interpretar el mal” (p. 126). Siguiendo este planteo, cuando más se cree en la dotación para justipreciar, valorar o tasar el mal, la experiencia literaria "lo pone en nuestras vidas y nos deja el placer de percibir la maniobra con que anula la facilidad de condenarlo" (p. 126) y así se sustrae el juicio neutralizando lo necesario con lo imposible y nunca aconteciendo la evaluación que siempre estamos en vías de cometer. 
Hace un tiempo conversamos con Rancière sobre estas dos cuestiones y las posibilidades de introducir, en los espacios educativos, maneras de hacer y decir vinculadas a ellas. En aquella charla hizo hincapié en la posibilidad de "preservar zonas de indeterminación en el seno del sistema escolar caracterizado por la compartimentación de saberes y la progresión jerarquizada de los aprendizajes", lo cual permitiría practicar la indisciplinariedad a partir de la "indeterminación en el contenido de ciertas disciplinas" y en contraposición a la interdisciplinariedad que impone el orden pedagógico como "recorte de la enseñanza en temas sobre los cuales cada disciplina está llamada a aportar su contribución”, que no es otra cosa que "un paso más en la saturación del espacio de aprendizaje a través de la distribución oficial de los saberes y sus modos de adquisición" (como se cita en Giuliano, 2017, p. 216). Como la experiencia docente podría indicarnos, esto no es sencillo y en más de una ocasión podría implicar una estrategia colectiva o cooperativa, porque se trata de una lucha al interior del sistema educativo por generar espacios y tiempos libres, es decir, sustraídos de objetivos previamente definidos, que permitan a enseñantes y estudiantes inventar o atravesar experiencias a partir de las cuales cada quien pueda hacer uso o ejercicio de la misma inteligencia y las mismas capacidades de percibir y de sentir. Siguiendo la huella de Rancière (como se cita en Giuliano, 2017), se trata de una “contra-educación” o una educación indisciplinada que, al devolver a la experiencia sensible su materialidad, es "condición previa de las actitudes que ofrecen confianza a los otros y hacen posible la construcción de mundos en común” (p. 218).

Pero la combinación de la lógica embrutecedora de la institución, entre la razón evaluadora y sus dispositivos pedagógicos, es parte de la "guerra científica contra la alodoxia" como continuación de "la guerra política contra la 'anomia' de los comportamientos", es decir, la "guerra contra la perturbación estética y democrática” del cuerpo popular, que indica Rancière (2012b). Tal vez justamente por esto, Deleuze (1996) opone la lucha a la guerra ${ }^{13}$ y ubica el juicio de Dios a favor de esta última, y no de la primera, pues incluso "cuando se apodera de otras fuerzas, la de la guerra empieza por mutilarlas o reducirlas a su estado más vil” (p. 186); por el contrario, la lucha sería "esa poderosa vitalidad no orgánica que completa la fuerza con la fuerza, y enriquece aquello de lo que se apodere" (p. 288). Tal vez por esto mismo es incompatible (y antagónica) con el juicio o la razón evaluadora, porque

13 A propósito de lo discutido en páginas anteriores, no está demás la aclaración que Agamben (2014) realiza sobre la analogía que los romanos veian entre la guerra y el proceso. 
la lucha "no es un juicio de dios, sino la manera de acabar de una vez con dios y con el juicio" (Deleuze, 1996, p. 187).

Así la lucha es contra el juicio, contra sus instancias (como la razón evaluadora, el culto evaluacionista, el reparto o la división de lo sensible, los dispositivos pedagógicos) y sus personajes (el pedagogo embrutecedor, el evaluador, el juez, la autoridad competente, "dios"). Pero esta lucha primero se libra en el propio luchador, entre sus partes juzgadoras y evaluadoras, entre fuerzas que subyugan o son subyugadas, entre las potencias que expresan estas relaciones de fuerzas, al decir de Deleuze (1996):

Todos los gestos son defensas o incluso ataques, regates, fintas, anticipaciones de un golpe que no siempre se ve llegar, o de un enemigo que no siempre se consigue identificar: de ahí la importancia de las posturas del cuerpo. Pero esas luchas exteriores, esas luchas-contra, encuentran su justificación en las luchas-entre que determinan la composición de las fuerzas en el luchador. Hay que distinguir la lucha contra el Otro y la lucha entre Sí. La lucha-contra trata de destruir o de repeler una fuerza (luchar contra "las potencias diabólicas del porvenir"), pero la lucha-entre trata por el contrario de apoderarse de una fuerza para apropiársela. (p. 184)

Como en ciertos deportes o artes marciales, los gestos toman formas de defensa, ataque, amagues, esquives o anticipaciones de un adversario que muchas veces convive dentro nuestro, a modo de un tipo de racionalidad en la que nos hemos formado (como la señalada a propósito del juicio, el examen o la evaluación) y afecta constitutivamente cada postura del propio cuerpo, pero que a partir de ello podemos sentir la composición de nuestras fuerzas como luchador para tratar de deshacer, resistir, rebatir, impugnar o repeler la fuerza del juicio y todas sus instancias. No se trataría tanto, como en el judo, de usar la fuerza del adversario en su contra sin aplicar esfuerzo, sino más bien de un ejercicio de resistencia que abre nuevas vías de re-existencia ética, política, estética y educativa.

Cabe decir algo más sobre la afección de dicha racionalidad en la propia corporalidad. Con Judith Butler conversamos específicamente sobre este punto que involucra las espacialidades educativas cruzadas por performatividades que han establecido parámetros normalizados de excelencia y rendimiento, modos de existencia corporal, lenguajes impostados y formas de estar, que responden al canon de la tradición 
educativa moderna con sus prácticas sexuadas heteronormativas - base de la vigilancia y sanción de cualquier desviación-. A propósito de ello sostiene que, desde el comienzo, las instituciones educativas enseñan dónde (y cómo) "poner el cuerpo: en la silla, en el piso, formando un círculo [...] Es un tipo de educación política y sexual" (como se cita Giuliano, 2017, pp. 167-168) ya que tal cuerpo pertenece a tal espacio en determinado momento y de determinada manera. Así se aprende a poner el cuerpo y cómo sostener y llevar el cuerpo es parte de un cierto tipo de interpelación: nos movemos de una determinada manera aprendiendo "modos de performatividad corporal para aprender cómo ser" [énfasis, fuera del original] (Butler, como se cita en Giuliano, 2017 p. 168). Por supuesto, esto podría conllevar castigos, así como formas de entusiasmo que "emergen ante la posibilidad de transgredir ciertas reglas [...] que procuran modelar el cuerpo como una especie de máquina productiva" (Butler, como se cita en Giuliano, 2017, pp. 168-169).

Enseñantes conservadores, neoliberales y progresistas, dependiendo la moda de turno, han coincidido históricamente en una defensa del juicio pedagógico, lo que configura todo un tipo de racionalidad evaluadora y un culto permanente a sus lógicas, además de una poderosa obsesión por la pregunta de cómo evaluar mejor a los sujetos. De este modo, incluso desde los comienzos de la modernidad (podríamos recordar aquí la "educación en el juicio" que recomendaba Montaigne en sus ensayos), se fue configurando todo un sistema de prácticas, tecnologías, mecanismos y dispositivos que han dado por hecho la sinonimia entre educación y juicio (u hoy, evaluación). Sus defensores y defensoras, desde el progresismo por su sentido "político-pedagógico" y desde el neoliberalismo por las "medidas de calidad” (entre otras) ${ }^{14}$, están convencidos de que privarnos del “juicio pedagógico” y la evaluación no nos permitiría diferenciar entre existentes y todo se tornaría equivalente — dando siempre lo mismo-. Esta (sobre)impresión, repetida con todas sus diferencias hasta el hartazgo, nos ha hecho descuidar que es el juicio y la razón evaluadora lo que supone criterios jerárquicos pre-existentes (o valores superiores) de tal modo que no queda lugar para sentir,

14 En esta línea, y con una agudeza sumamente vigente, podría recordarse a Roberto Arlt (2010) cuando en una de sus aguafuertes se pregunta quejosamente ¿para qué sirve el progreso? A lo que responde, entre otras cosas, que, además de ser uno de esos términos que embauca a la gente y se convierte en moneda de uso popular, es lo que produce una vida invivible en la que "respiramos a medida, dormimos con metro, nos despertamos automáticamente" (p. 17). Escribiendo desde la primera mitad del siglo $x x$, Arlt convida pistas de las relaciones entre progreso y medición (dos términos claves en lo que será el lenguaje de la razón evaluadora). 
percibir o experimentar lo que hay de nuevo en un existente o, incluso, la invención de un nuevo modo de existencia.

Por eso más que de enseñantes, se trata de evaluadores: gente más preocupada por cobrar que por enseñar o por vender que por dar, precisamente porque hacen de la enseñanza una transacción y una potencial deuda. Por eso más de una vez cualquier estudiante se esconde ante la presunción de evaluación o cuando esta resulta sorpresa, prefiere no estar, pasar desapercibido y, en ocasiones, hasta como desaparecido. Pues, en el fondo, el evaluador es un cobrador, una figura a la que una gran mayoría padece y aborrece, según analiza Roberto Arlt (2010), que "espanta como la del ángel que tocará la trompeta del juicio en el día postrero" y aparece cuando menos se lo espera "a amargarnos el almuerzo, a estropearnos la cena" con su "amplia sonrisa de apóstol y un oscuro pañuelo grande como una sábana para demostrarnos todos los trabajos crueles que tiene que sobrellevar" (p. 69), quien se dedica a hacerle "vomitar" el valor (en forma de memoria o saber) a sus prójimos. Así evaluar, como cobrar, "resuena en nuestros oídos como la trompa del juicio final" (Arlt, 2010, p. 66) y, en un tono burlón o amenazante, Arlt (2010) se dirige al cobrador (como al evaluador) y dice "Cobrar... ¡Cobrarías! ...” (p. 66) — siendo que cobrar también implica el sentido de una venganza o cierto castigo que los puntos suspensivos finales dejan en una radical incógnita.

Pero muy por el contrario de lo que la prensa pro evaluadora suele decir, es precisamente a partir del juicio y la razón evaluadora (con todas sus instancias) que las diferencias y los procesos se reducen a la lógica equivalencial de las cifras, y una inmensa cantidad de singularidades son clasificadas, comparadas y normalizadas de acuerdo a los parámetros predefinidos por los expertos, técnicos o, más precisamente, evaluadores. La vitalidad de la lucha, que a veces nos lleva al insomnio, no sin cierta ferocidad contra las instancias más íntimas, no resulta de la vereda del juicio y sus burócratas calificados, sino de la vereda de enfrente donde cierta escuela popular está cerrada al juicio y a sus cobradores/evaluadores pero abierta a la llegada de cualquier nuevo modo de existencia. Pues, como dice Deleuze (1996), el juicio impide la llegada de nuevas fuerzas que captan otras y valen por sí mismas, en tanto hace que exista una “nueva combinación”, lo cual traza cierta enseñanza:

Tal vez sea éste el secreto: hacer que exista, no juzgar. Si resulta tan repugnante juzgar, no es porque todo sea equivalente, sino por el contrario porque todo lo que vale sólo puede hacerse y distinguirse desafiando el juicio. (p. 188) 
Una educación indisciplinada o una contra-educación, entonces, tienen como bandera una lucha contra el juicio y su razón evaluadora. Por esto mismo, quizá, cobre un nuevo sentido la consigna histórica que pudo leerse en más de una movilización en defensa de la educación pública: “docente que lucha, también está enseñando”. A lo que podríamos agregar, tal vez, que los docentes que luchan sean los únicos que enseñan. Pero esta indisciplina educativa no solo está en manos de docentes, también está en los cuerpos de estudiantes que protestan, que toman sus instituciones, copian en sus exámenes o los resuelven colectivamente, que se enfrentan a la autoridad, que ingenian todo tipo de tácticas y estrategias para ganar tiempo libre en medio de la vorágine productivista que azota a las instituciones educativas, entre otras gestualidades y modos de invención, tal vez estas y estos estudiantes (como ha quedado constancia desde la Reforma del dieciocho) estén siendo las verdaderas figuras contemporáneas que se atreven a mirar fijamente la oscuridad en medio de las luces de su época.

\section{Referencias}

Agamben, G. (2001). Medios sin fin. Notas sobre la política. Valencia: Pre-Textos.

Agamben, G. (2005). Profanaciones. Buenos Aires: Adriana Hidalgo.

Agamben, G. (2011). Infancia e historia. Buenos Aires: Adriana Hidalgo.

Agamben, G. (2014). Desnudez. Buenos Aires: Adriana Hidalgo.

Agamben, G. (2015). Idea de la prosa. Buenos Aires: Adriana Hidalgo.

Arlt, R. (1975/2010). Nuevas aguafuertes. Buenos Aires: Losada.

Benjamin, W. (2005). El capitalismo como religión. En El libro de los pasajes (pp. 97-49). Madrid: Akal.

Bourriaud, N. (2009). Radicante. Buenos Aires: Adriana Hidalgo.

Buck-Morss, S. (1995). Dialéctica de la mirada. Walter Benjamin y el proyecto de los Pasajes. Madrid: Visor.

Cambaceres, E. (2006). En la sangre. Buenos Aires: Colihue.

Deleuze, G. (1996). Crítica y clínica. Barcelona: Anagrama. 
Foucault, M. (1994). La hermenéutica del sujeto. Madrid: La Piqueta.

Giuliano, F. (2017). Rebeliones éticas, palabras comunes. Conversaciones (filosóficas, politicas, educativas) con Judith Butler, Raúl Fornet-Betancourt, Walter Mignolo, Jacques Rancière, Slavoj Žižek. Buenos Aires: Miño y Dávila.

Giuliano, F. (2019). Entonces, ¿qué es un dispositivo? De la matriz colonial de poder a los dispositivos (pedagógicos) contemporáneos. Voces de la educación, 4(8), 28-68. Recuperado de: https://dialnet.unirioja.es/servlet/articulo?codigo=7017237

González, H. (1996/2008). Arlt: política y locura. Buenos Aires: Colihue.

Kohan, W. (2004). Infancia entre educación y filosofía. Barcelona: Laertes.

Kusch, R. (2007). Obras completas: V. III . Rosario: Fundación Ross.

Larrosa, J. (1995). Tecnologías del yo y educación. En J. Larrosa (ed.), Escuela, poder, subjetivación (pp. 257-361). Madrid: La Piqueta.

Mèlich, J. C. (2014). Lógica de la crueldad. Barcelona: Herder.

Mercado, T. (1988/2006). Canon de alcoba. Buenos Aires: Seix Barral.

Mignolo, W. (2003). Historias locales/diseños globales. Colonialidad, conocimientos subalternos y pensamiento fronterizo. Madrid: Akal.

Nietzsche, F. (2013). Crepúsculo de los ídolos o cómo se filosofa con el martillo. Madrid: Alianza.

Rancière, J. (1991). Breves viajes al país del pueblo. Buenos Aires: Nueva Visión.

Rancière, J. (2009). El reparto de lo sensible. Santiago de Chile: lom.

Rancière, J. (2010). El espectador emancipado. Buenos Aires: Manantial.

Rancière, J. (2012a). El desacuerdo. Política y filosofía. Buenos Aires: Nueva Visión.

Rancière, J. (2012b). Pensar entre disciplinas. En G. Frigerio y G. Diker (comps.), Educar: (sobre)impresiones estéticas (pp. 73-86). Buenos Aires: Del estante.

Skliar, C. (2011). Lo dicho, lo escrito, lo ignorado. Ensayos mínimos entre educación, filosofía y literatura. Buenos Aires: Miño y Dávila. 
Walsh, M. E. (2015). Poemas y canciones. Buenos Aires: Alfaguara.

Žižek, S. (1998/2008). Multiculturalismo, o la lógica cultural del capitalismo multinacional. En F. Jameson y S. Žižek, Estudios culturales. Reflexiones sobre el multiculturalismo (pp. 137-188). Buenos Aires: Paidós.

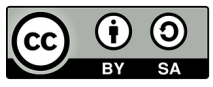

